\title{
Role of Information Professionals in Knowledge Management Programs: Empirical Evidence from Canada
}

\author{
Isola Ajiferuke \\ University of Western Ontario, London, Canada \\ iajiferu@uwo.ca
}

\begin{abstract}
The objective of this study is to provide empirical evidence of the role of information professionals in knowledge management programs. 386 information professionals working in Canadian organizations were selected from the Special Libraries Association's Who's Who in Special Libraries 2001/2002 and questionnaire with a stamped self-addressed envelope for its return was sent to each one of them. 63 questionnaires were completed and returned, and 8 in-depth interviews conducted. About $59 \%$ of the information professionals surveyed are working in organizations that have knowledge management programs with about $86 \%$ of these professionals being involved in the programs. Factors such as gender, age, and educational background (i.e. highest educational qualifications and discipline) did not seem to have any relationship with involvement in knowledge management programs. Many of those involved in the programs are playing key roles, such as the design of the information architecture, development of taxonomy, or content management of the organization's intranet. Others play lesser roles, such as providing information for the intranet, gathering competitive intelligence, or providing research services as requested by the knowledge management team.
\end{abstract}

Keywords: Knowledge management, information professionals, Canada, business organizations

\section{Introduction}

Knowledge management is a collection of processes that govern the creation, dissemination, and utilization of knowledge in an organization (Newman, 1991). It involves the management of explicit knowledge (i.e. knowledge that has been codified in documents, databases, web pages, etc.), and the provision of an enabling environment for the development, nurturing, utilization and sharing of employees' tacit knowledge (i.e. know-how, skills, or expertise). The implementation of an appropriate knowledge ma nagement program in a business organization has the potential of improving customer services, continually improving business processes, quickly bringing new products to markets, and bringing innovative new ideas to commercialization (Heisig \& Vorbeck, 2001).

In most organizations, the key professionals involved in knowledge management activities are human resource managers, process \& product developers, and information technologists (Ta ylor, 2001). This assertion was partly corroborated by a bibliometric analysis of the field of knowledge ma nagement that showed that the field's popularity was largely due to the dominance of information technology applica-

Material published as part of these proceedings, either on-line or in print, is copyrighted by Informing Science. Permission to make digital or paper copy of part or all of these works for personal or classroom use is granted without fee provided that the copies are not made or distributed for profit or commercial advantage AND that copies 1) bear this notice in full and 2) give the full citation on the first page. It is permissible to abstract these works so long as credit is given. To copy in all other cases or to republish or to post on a server or to redistribute to lists requires specific permission from the publisher at Publisher@InformingScience.org tions (Wolfe, 2003). However, of late, there has been increased interest in knowledge management activities by information professionals. To demonstrate the relevance of the profession to know ledge management, various articles have discussed the roles of information profe ssionals in the knowledge management process (Albert, 1998; Balcombe, 1999; Broadbent, 1998; Duffy, 2000; Marshall, 1997; Milne, 2000; Ponelis \& Fairer- 


\section{Role of Information Professionals}

Wessels, 1998; Schwarwalder, 1999; Yeh, 2000); special issues of professional journals have been devoted to knowledge management issues; a book on knowledge management for the information professional has been published (Srikantaiah \& Koenig, 2000); special sessions on knowledge management have been held at professional conferences; seminars on knowledge management are being organized regularly; some library and information science schools now offer courses on knowledge management, such as "Knowledge Management in Organizations" at the School of Communication, Information and Library Studies at Rutgers University; and a few schools have even gone a step further by offering specialization in knowledge management, such as the Innovative Master of Science in Information Architecture and Knowledge Management at Kent State University, United States of America, or the Master of Science in Knowledge Mangement at the School of Communication and Information, Nanyang Technological University, Singapore.

Despite the activities listed above, there is little evidence of the involvement of information professionals in organization's knowledge management programs (Abell, 2000). Hence, the general objective of this study is to obtain empirical evidence of information professionals' involvement in knowledge ma nagement activities in Canada. Specifically, the objectives are to determine the:

- degree of involvement of information professionals in KM activities in Canadian business organizations;

- specific roles being performed by the information professionals;

- skills required by the information professionals to participate effectively in KM activities;

- and factors inhibiting the participation of information professionals in KM activities.

\section{Previous Research}

There have been various empirical studies conducted on knowledge management practices but these have been from the business or information technology perspective. For example, Ruggles (1999) conducted a survey of 431 organizations in the U.S. and Europe but the focus was on what the organizations were doing to manage knowledge and the software being used, as well as the obstacles encountered in implementing knowledge management programs. In another study, Heisig \& Vorbeck (2001) conducted a comprehensive survey of the German TOP 1000 and European TOP 200 companies. The survey que stions focused on the status of knowledge management activities in the business processes. Also, Kautz (2002) investigated the use of an IT-supported knowledge management system (KMS) that is embedded in knowledge management framework in a large, global IT consulting company. The study found that the majority of the respondents were using the KMS to search for ge neral information but not as the primary repository and communication media for knowledge assets.

At the national level in Canada, a couple of surveys have also been conducted on knowledge management practices. Stivers, Covin, Hall and Smalt (1997) conducted a study to provide a broad-based empirical overview of some of the key issues in knowledge management. Questionnaires were sent to the top executives of 300 of the Financial Post 500 firms in Canada and all of the Fortune firms in the U.S. The results of the study showed that knowledge management practices (e.g. putting mechanisms in place to ensure that intellectual assets are retained by the company) were perceived to be fairly common in Canadian and U.S. firms. Statistics Canada conducted a pilot survey (Earl, 2002) on knowledge management practices in the fall of 2001 as part of an international initiative headed by the Organization for Economic Cooperation and Development. Questionnaires were sent to 407 firms in five sub-sectors of the North American Industrial Classification System: forestry and logging; chemical manufacturing; transportation equipment manufacturing; machinery, equipment and supplies whoksaler-distributors; and management, scientific and technical consulting services. The study found that a majority of the firms were engaged in at least one of 23 business practices related to knowledge management. On the 
issue of who was responsible for knowledge management practices in the firms, the study found that the executive management team was responsible in $68 \%$ of the firm, information technology unit in $7 \%$, human resources unit in $6 \%, 6 \%$ of the respondents didn't know, and the remaining $12 \%$ chose knowledge management unit, library/documentation centre or multiple responses. This result is not totally surprising, as we don't expect the library/documentation centre to have direct responsibility for knowledge management practices in an organization. However, our contention is that information professionals do have a role to play, and the aim of this study is to determine what this role is.

\section{Methodology}

This study employed the survey research methodology and potential subjects for the study were obtained from the Special Libraries Association's Who's Who in Special Libraries 2001/2002 (Special Libraries Association, 2002). The directory listed 564 information professionals belonging to the Toronto chapter, 253 from Eastern Canada chapter, and 243 from Western Canada chapter. After eliminating duplicates (i.e. those belonging to more than one chapter), 231 members were purposively selected from the Toronto chapter, 81 from Western chapter, and 74 from Eastern chapter. Those not selected included student members, retired members, university professors, those working in public or academic libraries, those with only residential addresses (which made it impossible to determine the type of organization they were working in), and those based outside Canada (e.g. France and United Arab Emirates). A questionnaire with a stamped self-addressed envelope for its return was sent to each of the 386 selected members. Some of the questionnaires were returned because the respondents had moved, one respondent from Quebec requested that the questio nnaire should be translated into French for her (this was not done since she was the only one making such a request whereas about 11 other respondents from Quebec completed and returned the questionnaire), and a few others indicated that they would not be able to participate in the study either because they were not working in an environment where KM was being practiced or they were not familiar with the concept. In all, 63 completed questionnaires were returned. This represents a response rate of about $16 \%$.

In order to obtain in-depth information about the experience of the information professionals in knowledge management programs, 20 professionals belonging to the knowledge management section of the Special Libraries Association from the Toronto chapter were selected for interviews. These people were selected because of their perceived interest in knowledge management, Toronto's proximity to the researcher's base, and the fact that many industrial/business organizations are located in the city. In add ition, an alumnus of the Faculty of Information and Media Studies, University of Western Ontario, who works as a director of knowledge management in a public relations/public affairs consulting firm in Toronto, also provided names of some other information professionals involved in knowledge management in Toronto. Initial contact was made with each of the potential interviewees but a few did not respond while four indicated that, though knowledge management was being practiced in their organization, they were not directly involved in the program. Eventually, only 8 agreed to sit down for the interview. Each interviewed lasted for about 45 - 90 minutes.

The data collected by questionnaire were subjected to quantitative analysis using SPSS software while the interview sessions were recorded on tape, transc ribed and analyzed qualitatively.

\section{Results and Discussions}

\section{Background of Respondents}

The respondents work in various organizational settings with the three major ones being Business \& Finance, Consulting, and Insurance and Employee Benefits. It was encouraging to see that many of the respondents come from these types of organizations, which are known to be heavily involved in knowledge management (Earl, 2002). According to Earl, the main reason is that these service industries de- 


\section{Role of Information Professionals}

pend to a great extent upon marketing the application of the knowledge of their workers. A large majority $(82.5 \%)$ of the respondents are female, which is not surprising as the profession is dominated by women. Almost half of the respondents are between 36 and 45 years old (see Figure 1) with the remaining ones almost evenly split between the age brackets $26-35$ years and $46-55$ years.

In terms of educational qualifications, most of the respondents have a master's degree in library and information science (this includes master's degree in library science, master's degree in information management, master's degree in information technology, and master's degree in archival studies) in addition to a first degree in either Social Sciences or Arts \& Humanities (see Figures $2 \& 3$ ). This is in line with the general practice in the profession. In addition to the degrees, some have also attended workshops or continuing education courses in order to update their knowledge. For example, one of the information professionals interviewed mentioned that he's had to take a course in web design that was not available when he was in school.

Figure 1: Age of respondents

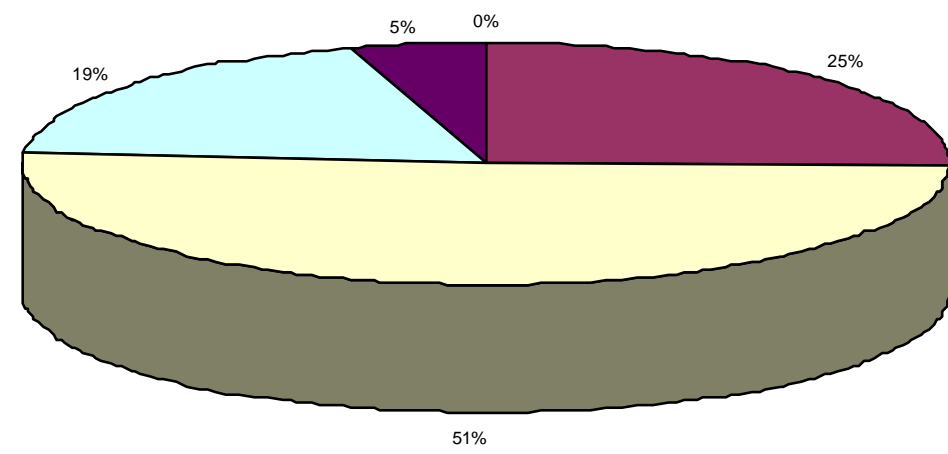

Figure 2 : Highest Educational Level

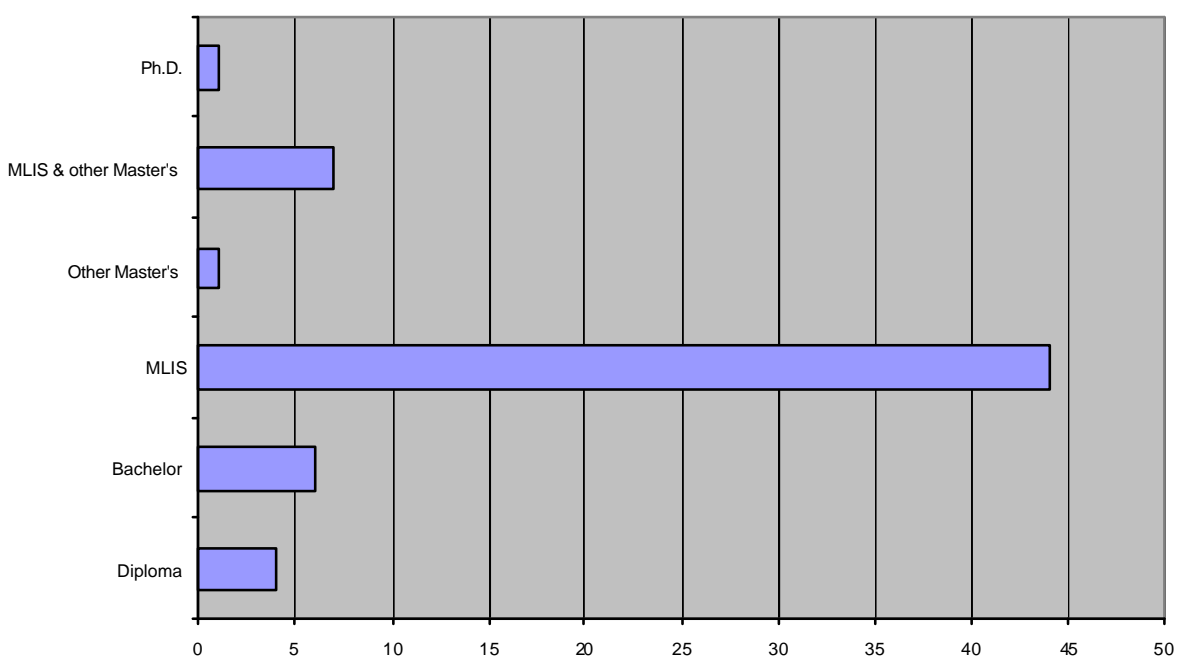


Figue 3 : First Degree's Subject Discipline

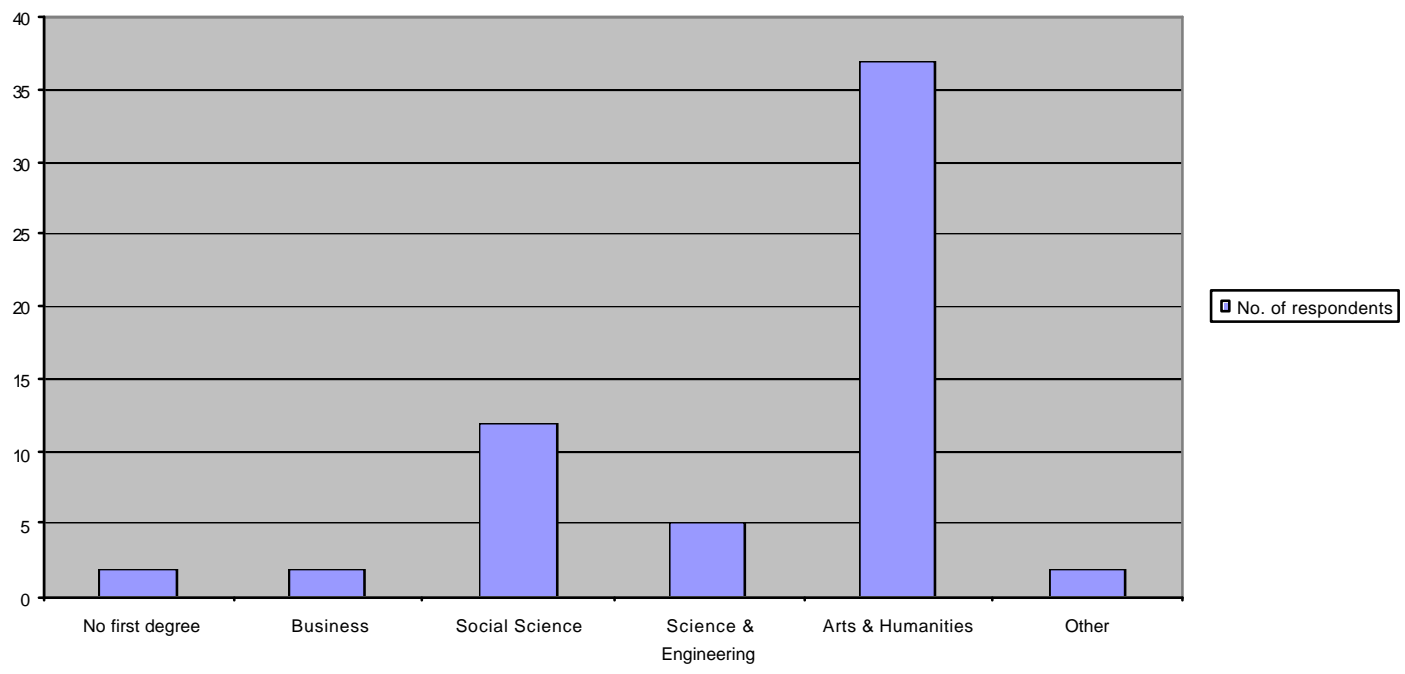

Figure 4 : Source of Knowledge about KM

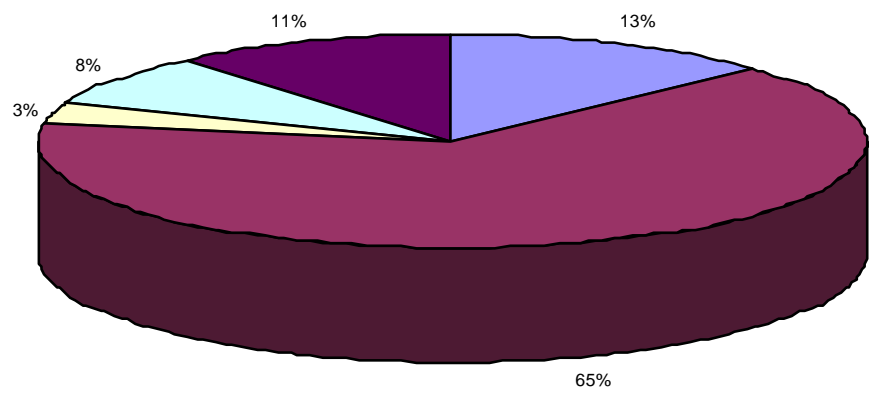

At a professional conference

$\square$ Read about it in the literature

$\square$ Attended a workshop on it

ㅁ t took a course on it in school

\section{Perceptions of Knowledge Management}

Most of the respondents first read about knowledge management in the literature but very few had taken a course on it (see Figure 4). This is understandable as knowledge management is now a hot topic in the literature of the profession but only a few schools are offering a course in knowledge management.

Most of the professionals disagreed that knowledge management is just another fad like total quality management (see Table 1), which corroborates the findings by Ponzi \& Koenig (2002) that knowledge management is at least lasting more than typical fads and, perhaps, is in the process of establishing itself as a new aspect of management. However, the respondents were equally divided on whether knowledge management is a new term for what information professionals used to do. Also, a majority of them agree that information management is just an aspect of knowledge management, which is in line with the thinking that information management involves management of explicit knowledge (e.g. documents) while knowledge management involves the management of both explicit knowledge and tacit knowl- 
Role of Information Professionals

edge. Not surprisingly, there was almost a unanimous agreement that information professionals have important roles to play in knowledge management programs.

\begin{tabular}{|l|l|l|l|l|l|}
\hline & $\begin{array}{l}\text { Strongly } \\
\text { Disagree }\end{array}$ & Disagree & Not Sure & Agree & $\begin{array}{l}\text { Strongly } \\
\text { Agree }\end{array}$ \\
\hline $\begin{array}{l}\text { KM is just another } \\
\text { fad like Total Qual- } \\
\text { ity Management }\end{array}$ & $\begin{array}{l}10 \\
(15.9 \%)\end{array}$ & $\begin{array}{l}38 \\
(60.3 \%)\end{array}$ & $\begin{array}{l}8 \\
(12.7 \%)\end{array}$ & $6(9.5 \%)$ & $1(1.6 \%)$ \\
\hline $\begin{array}{l}\text { KM is a new term } \\
\text { for what informa- } \\
\text { tion professionals } \\
\text { were already doing }\end{array}$ & $3(4.8 \%)$ & $\begin{array}{l}26 \\
(41.3 \%)\end{array}$ & $5(7.9 \%)$ & $\begin{array}{l}24 \\
(38.1 \%)\end{array}$ & $4(6.3 \%)$ \\
\hline $\begin{array}{l}\text { Information man- } \\
\text { agement is just an- } \\
\text { other aspect of KM }\end{array}$ & $1(1.6 \%)$ & $\begin{array}{l}13 \\
(20.6 \%)\end{array}$ & $3(4.8 \%)$ & $\begin{array}{l}36 \\
(57.1 \%)\end{array}$ & $9(14.3 \%)$ \\
\hline $\begin{array}{l}\text { Information profes- } \\
\text { sionals have impor- } \\
\text { tant roles to play in } \\
\text { KM programs }\end{array}$ & $0(0.0 \%)$ & $0(0.0 \%)$ & $2(3.2 \%)$ & $\begin{array}{l}30 \\
(47.6 \%)\end{array}$ & $\begin{array}{l}31 \\
(49.2 \%)\end{array}$ \\
\hline
\end{tabular}

Table 1: Perceptions of knowledge management

\section{Role in Knowledge Management Programs}

Thirty seven (59\%) of the information professionals are working in organizations which have knowledge management programs. Most of these organizations are in the process of integrating knowledge management principles into their daily activities (see Figure 5) while the majority of the programs (about $86.1 \%$ ) are less than 5 years old (see Figure 6). In fact, the information professionals interviewed mentioned that most organizations practicing knowledge management are still trying to fiddle their way round and that the main concrete activity seems to be the sharing of knowledge especially through the aid of the organization's intranet. This view is buttressed by the fact that one can reasonably argue that

Figure 5 : Status of KM Program

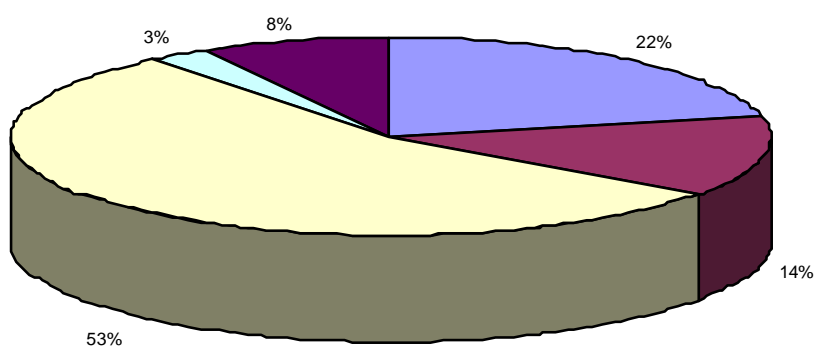


Figure 6 : When KM Program was launched

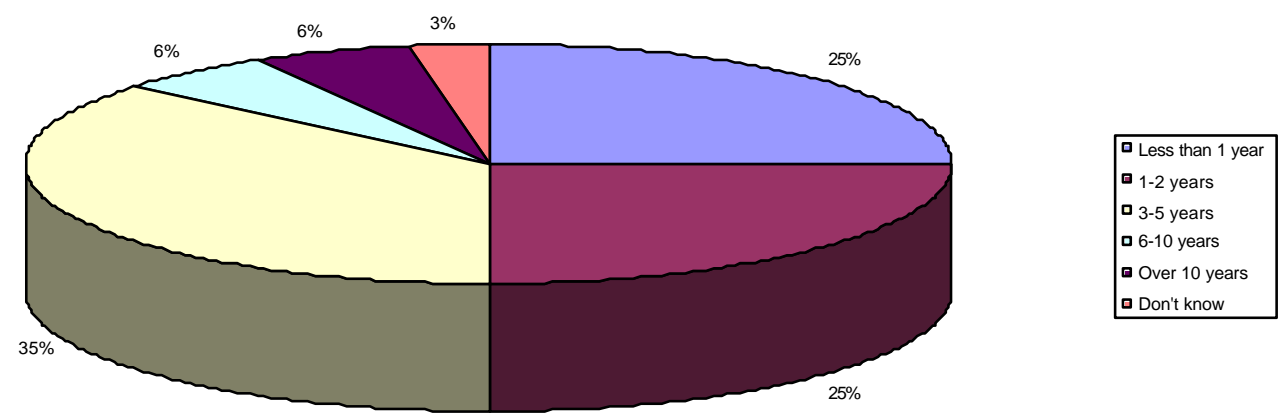

some of the 23 knowledge management practices (categorized under "policy and strategies", "leadership", "incentives", "training and mentoring", and "communications") identified in the Statistics Canada pilot survey on knowledge management practices (Earl, 2002) are normal business practices.

Thirty-two (about 86\%) out of the information professionals working in organizations with knowledge management programs are involved in such programs. Factors such as gender, age, and educational background did not seem to have any relationship with involvement in knowledge management programs (each of the tested hypotheses of a relationship between involvement in knowledge management program and gender, age or educational background turned out to be non-significant). In fact, the key reason given by the few for non-involvement is the lack of management's recognition of the roe of information professionals in knowledge management.

In terms of the degree of involvement, about half of the information professionals regarded themselves as key members of the knowledge management team, about 30\% regarded themselves as non-key members of the team, while a very few number are playing leadership roles (see Figure 7). Some of the key roles being played by information professionals include the design of the information architecture, development of taxo nomy, and content management (one of the professionals interviewed, who had taken a course in Lotus Notes Development, trains the content managers) of the organization's intranet. In support of these roles, more and more job adverts seeking portal content managers now list a master's degree in library and information science as one of the required qualifications. The non-key roles being played by information professionals include provision of information for the intranet (includes internal information as well as external information gathered through Internet and online database searching), distribution of electronic information, gathering competitive intelligence, and provision of research services as requested by the knowledge management team. One of the two respondents playing leadership roles claimed to have introduced the program to the organization while the other one is responsible for developing the process for knowledge generation, capture and exchange within the organization. Also, one of the professionals interviewed is the director of knowledge management services for a branch office of a consulting firm. She is part of the knowledge management team for the firm but the main leadership direction emanates from the headquarters. 


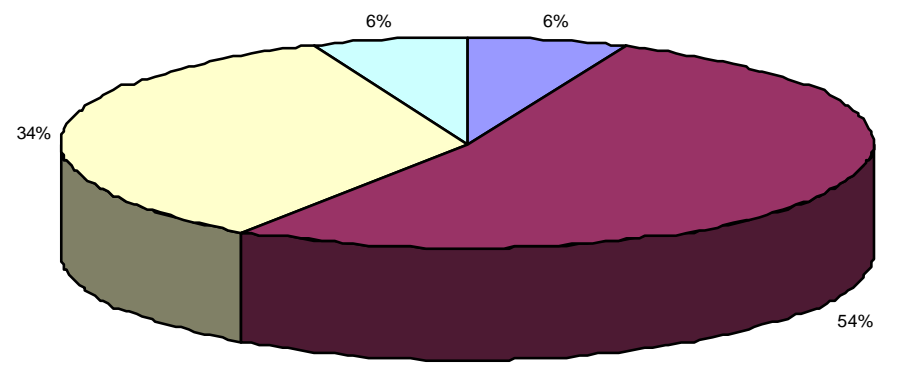

Based on their experience, the respondents identified team working, communication and networking skills as the key organizational skills required by information professionals (see Table 2) in order to be able to participate in knowledge management programs. This result validates some of the skills earlier identified by Abell (2000). Team working and communication skills are required for collaboration within an organization while communication and team networking skills are required for the sharing and transfer of knowledge.

\begin{tabular}{|l|l|}
\hline Skills & $\begin{array}{l}\text { Number of Respon- } \\
\text { dents }\end{array}$ \\
\hline $\begin{array}{l}\text { Communication } \\
\text { skills }\end{array}$ & $31(96.9 \%)$ \\
\hline $\begin{array}{l}\text { Leadership } \\
\text { skills }\end{array}$ & $25(78.1 \%)$ \\
\hline $\begin{array}{l}\text { Facilitation } \\
\text { skills }\end{array}$ & $24(75.0 \%)$ \\
\hline $\begin{array}{l}\text { Networking } \\
\text { skills }\end{array}$ & $22(64.4 \%)$ \\
\hline $\begin{array}{l}\text { Negotiating } \\
\text { skills }\end{array}$ & $24(75.0 \%)$ \\
\hline $\begin{array}{l}\text { Consensus } \\
\text { building skills }\end{array}$ & $21(65.6 \%)$ \\
\hline $\begin{array}{l}\text { Persuasion } \\
\text { skills }\end{array}$ & $32(100.0 \%)$ \\
\hline Team working & $21(65.6 \%)$ \\
\hline Coaching skills & $18(56.3 \%)$ \\
\hline Mentoring skills
\end{tabular}

Table 2: Organizational Skills and Competencies Required in KM Programs

(percentage given with regard to the number of respondents involved in knowledge management programs) 
The respondents also identified the ability to analyze business processes, understanding of the knowl edge process within the business process, ability to use information technologies, and document management skills (see Table 3 ) as the core competencies required of information professionals in knowledge management programs. The ability to analyze business processes and understanding of the know $1-$ edge process within the business process are required for knowledge generation/creation. Even if information professionals don't create know ledge, it would be necessary for them to have these skills so as to be able to collaborate with colleagues on a knowledge management team. In fact, one of the professio nals interviewed mentioned that she had to take a correspondence course from the Canadian Securities Institute in order to have a better understanding of the business process (accounting, auditing, stock brokering, etc.) that her organization is involved in. The ability to use technology is necessary for the information professionals to perform some of the roles that have been identified above (i.e. content management of an intranet, database searching, etc.). Document management skills, which information professionals are well known for, are definitely required for managing explicit knowledge.

\begin{tabular}{|l|l|}
\hline \multicolumn{1}{|c|}{ Skills } & Number of Respondents \\
\hline $\begin{array}{l}\text { Ability to identify and analyse } \\
\text { business processes }\end{array}$ & $32(100.0 \%)$ \\
\hline $\begin{array}{l}\text { Understanding of the knowledge } \\
\text { process within the business proc- } \\
\text { ess }\end{array}$ & $31(96.9 \%)$ \\
\hline $\begin{array}{l}\text { Ability to use information tech- } \\
\text { nologies }\end{array}$ & $27(84.4 \%)$ \\
\hline Change management skills & $21(65.6 \%)$ \\
\hline Project management skills & $27(84.4 \%)$ \\
\hline $\begin{array}{l}\text { Document and information man- } \\
\text { agement skills }\end{array}$ & $30(93.8 \%)$ \\
\hline
\end{tabular}

Table 3: Core Competencies Required in KM Programs

(percentage given with regard to the number of respondents involved in knowledge management programs)

Finally, the respondents appreciated the efforts being made by organizations such as the American Society for Information Science \& Technology which organizes regular seminars at its annual meeting, and Special Libraries Association which features regular articles on knowledge management in its publication "Information Outlook". However, they would like the professional bodies to develop a program of awareness activities that target corporate sector organizations to demonstrate the potential roles that information professionals can play in knowledge management programs. Hopefully, these awareness activities would go a long way in convincing business executives of the need to include information professionals on their knowledge management teams. Some of the respondents would also like the professional bodies to organize courses to educate the professionals on knowledge management concepts and principles. One of the interviewees also suggested that information professionals might want to enrol for a knowledge certification program that would certify their competencies in knowledge management. There are at least two of such programs, Certified Knowledge and Innovation Management-Commercial (CKIM-C) Program, and Knowledge Economics and Management Certification Training Program. However, such programs are expensive and one is not sure how well these programs are recognized by commercial organizations.

The respondents also would like the library and information science schools to develop and offer a course in knowledge management for their students. A few of the respondents disagreed and suggested that it would be better for the schools to collaborate with business schools in offering the course. How- 


\section{Role of Information Professionals}

ever, according to Koenig (1999), the emphasis and perspective taken by the business school might be different. At present, at least four of the library and information science schools in Canada are offering courses in knowledge management while one of them, which has a joint MLIS/LLB programme, collaborates with the business school to offer the course. Students in the remaining schools without a knowledge management course would be well advised to take online information retrieval, cataloguing and classification, and web design \& management courses as well as read the literature to familiarize themselves with the concepts of knowledge management if they intend to apply for knowledge management-related jobs in the future. It is interesting to note that none of the respondents suggested that Canadian library and information science schools should emulate some of their United States counterparts (e.g. Kent State University, Dominican University, and University of Oklahoma-Tulsa) by offering a master's degree program in knowledge management. It is the assumption that they probably felt it is not necessary at this time. Hopefully, more light will be shed on this issue when the outcome of the study on knowledge management professional competencies by Alycia Tulloch, a candidate in Emporia State University's library and information management's master's degree program, is published. One of the objectives of her study was to determine whether knowledge management professional competencies can be learned through formalized instruction, and if so, should this be called a master's degree in knowledge management.

\section{Conclusion}

This paper provides empirical evidence that most of the information professionals working in Canadian organizations with knowledge management programs are involved in such programs. The key reason for non-involvement of a few of them is lack of management's recognition of the role of information professionals in knowledge management. The major roles being performed by information professionals in knowledge management programs include the design of the information architecture, development of the taxonomy, and content management of the organization's intranet while the minor roles include the provision of information for the intranet, gathering competitive intelligence, or providing research services as requested by the knowledge management team. Also, team working, communication, ne tworking and analytical skills were identified as the most important organizational skills required by information professionals to function in knowledge management programs while understanding of the knowledge process within the business process, ability to use information technologies, and document management skills were identified as the most important required competencies.

In conclusion, even though the recent global economic downturn has prompted many companies to scrap knowledge management posts or to reduce the scope of their knowledge management programs (Pringle, 2003), information professionals should continue to strive to be relevant in the field of knowledge management in anticipation of its resurgence in the nearest future.

\section{Acknowledgement}

The funding for this study was provided by the Faculty of Information and Media Studies, University of Western Ontario, London, Canada.

\section{References}

Albert, J. (1998). Nuts and bolts of knowledge management for information professionals. Proceedings of the National Online Meeting, 19 (1), 7-15.

Abell, A. (2000). Skills for knowledge environments. Information Manag ement Journal, 34(3) 33 -41.

Balcombe, J. (1999). Getting out of the box : The role of the information professional in Knowledge management. The Law Librarian, 31(2), 91-94.

Broadbent, M. (1998). The phenomenon of knowledge management : what does it mean to the information profession ? Information Outlook, 2(5), 23-36. 
Duffy, J. (2000). Knowledge management: What every information professional should know. Information Management Journal, 34(3), 10-18.

Earl, L. (2002). Are we managing our knowledge?: Results from the pilot knowledge management practices survey, 2001. [Online] Available at : http://www.statcan.ca/english/IPS/Data/88F0006XIE2002006.htm

Heisig, P. \& Vorbeck, J. (2001). Benchmarking survey results. In : Mertins, K., Heisig, P. \&Vorbeck, J., ed., Knowledge management : Best practices in Europe. Berlin: Springer- Ve rlag.

Kautz, K. (2002). Using IT to support knowledge management - A survey-based study of a large, global consulting company. IS2002 Proceedings of the Informing Science + IT Education Conference, 783-793.

Koenig, M.E.D. (1999). Education for knowledge management. Information Services \& Use, 19, 17-31.

Marshall, L. (1997). Facilitating knowledge management and knowledge sharing: New opportunities for information professionals. Online, 21(5), 92-98.

Mline, P. (2000). Information professionals and the knowledge aware, intelligent organization: Skills for the future. Australian Library Journal, 49(2), 139-151.

Newman, B. (1991). An open discussion of knowledge management. [Online]. Available : http://www.kmforum.org/what is.htm.

Ponelis, S. \& Fairer-Wessels, F.A. (1998). Knowledge management: a literature overview. South African Journal of Library and Information Science, 66(1), 1-9.

Ponzi, L. \& M. Koenig (2002). Knowledge management: Another management fad? Information Research, 8(1) [Available at http://InformationR.net/ir/8-1/paper45.html].

Pringle, D. (2003). Bear bites knowledge officers. Globe \& Mail, January 7, p. B8.

Ruggles, R. (1999). The state of the notion: Knowledge management in practice. In: Cortada, J.W. \& Woods, J.A. , ed., The KM Yearbook 1999-2000. Bos ton: Butterworth-Heinemann.

Schwarzwalder, R. (1999). Librarians as knowledge management agents. Econtent, 22(4), 63-65.

Special Libraries Association. (2002). Who's Who in Special Libraries 2001/2002. Washington, DC: Special Libraries Association.

Stivers, B.P., T.J. Covin, N.G. Hall \& S.W. Smalt (1997). Harnessing corporate IQ. CA Magazine, v. 130 (April), 26 -29.

Srikantaiah, K. \& Koenig, M.E.D., ed. (2000). Knowledge management for the information professional. Medord, NJ: Information Today.

Taylor, R.M. (1996). Knowledge management. [Online]. Available at http://ourworld.compuserv.com/homepages/roberttaylor/km.htm.

Wolfe, M. (2003). Mapping the field: knowledge management. Canadian Journal ofCommunication, 28, 85-109.

Yeh, N. (2000). Knowledge management and the future of libraries. Journal of Information, Communication and Library Science, 6(3), 81-94.

\section{Biography}

Isola Ajiferuke is an assistant professor at the Faculty of Information and Media Studies, University of Western Ontario, Canada. Dr Ajiferuke has previously lectured at the Africa Regional Centre for Information Science, Nigeria, and the Department of Library and Information Studies, University of Botswana, Botswana. His areas of research interests include the impact of information technology on development, knowledge management, informetrics, and modeling of information systems. 